\section{Joel e a esperança em um Deus universal e libertador frente à ambiguidade do monoteísmo*}

\author{
Luiz Alexandre S. Rossi** \\ Natalino das Neves***
}

RECIBIDO: 29-03-16. APROBADO: 23-11-16

Resumo: O artigo tem por objetivo comparar os resultados entre as principais reformas políticoreligiosas em nome do monoteísmo em Israel com a mensagem de Joel. Descrever-se-á as reformas de Ezequias e Josias, e a reforma étnica de Esdras e Neemias. Na sequência, é apresentada a mensagem universalista e libertadora de Joel, com destaque para as perícopes de Joel 3,1-5 e 4,4-8, visando a comparação entre esta e aquelas. Trata-se de uma pesquisa essencialmente bibliográfica. $\mathrm{O}$ resultado evidencia que a instituição do monoteísmo foi ambígua, oscilando entre opressão e humanização. Enquanto as reformas monárquicas e de Esdras e Neemias serviram mais a objetivos políticos e de dominação, a mensagem de Joel contribuiu para açóes mais inclusivas e libertadoras.

Palavras-chave: Joel, monoteísmo, imperialismo, opressão, modo de produçâo escravista.
Joel and the Hope in a Universal and Liberating God before the Ambiguity of Monoteism

Aвstract: The article aims to compare the results of Israel's main political-religious reforms in the name of monotheism with the message of Joel. It describes the reforms of Hezekiah and Josiah, and also the ethnic reform of Ezra and Nehemiah. Later, these reforms are compared with Joel's universalist and liberating message, stressing on the pericopes of Joel 3,1-5 and 4,4-8. Thus, this is mainly a bibliographical research. The result of this research shows that the institution of monotheism was ambiguous and it oscillated between oppression and humanization. While Ezra and Nehemiah's monarchist reform served to political and domination purposes, Joel's message contributed to more inclusive and liberating actions.

KeY-words: Joel, Monotheism, Imperialism, Oppression, Slavery, Mode of Production.

PARA CITAR ESTE ARTÍCULO:

Rossi, Luiz Alexandre y Natalino das Neves. "Joel e a esperança em um Deus universal e libertador frente à ambiguidade do monoteísmo". Theologica Xaveriana 184 (2017): 461-479. https://doi.org/ 10.11144/javeriana.tx67-184.jedulf

* Artigo de investigaçáo ligado ao Programa de Mestrado e Doutorado em Teologia da Pontifícia Universidade Católica do Paraná e inserido no grupo de pesquisa Bíblia e Pastoral.

${ }^{* *}$ Luiz Alexandre Solano Rossi: Doutor em Ciências Sociais e Religião, UMESP; pós-doutor em História Antiga, Unicamp, e pós-doutor em Teologia, Fuller Theological Seminary, California. Professor no Programa de Pós-Graduação da Pontifícia Universidade Católica do Paraná, PUCPR. Orcid: 0000-0002-3270-135X. Correio eletrônico: luizalexandrerossi@yahoo.com.br

*** Natalino das Neves: Doutorando em Teologia e Mestre em Teologia no Programa de Pós-Graduação da Pontifícia Universidade Católica do Paraná, PUCPR. OrCid: 0000-0002-1966-2851. Correio eletrônico: natalino6612@gmail.com 


\section{Introdução}

A Bíblia, em princípio, é um produto da memória subversiva dos menos favorecidos, enfraquecidos ou oprimidos ${ }^{1}$. Entretanto, em termos históricos, as diferentes tradiçóes oriundas das reformas religiosas em Israel foram fixadas em ambientes de opressão e exploração humana. Os textos bíblicos se interpretados, considerando esta abordagem, despertam uma memória libertadora, de resistência e sobrevivência, a exemplo da busca constante de liberdade pelo povo de Israel. Lopez ${ }^{2}$ afirma que o Deus bíblico não se dá conhecer pela sua essência, mas pela sua ação libertadora na história do povo de Israel.

O texto bíblico, diferente do que se espera de um livro sagrado, contém vários relatos de violência e incitação a atos de violência, que ao longo da história de Israel são tidos como lícitos e, acima de tudo, sagrados. Segundo Dietrich, esse processo vai do politeísmo ao monoteísmo. Entretanto, ressalta que "esse movimento em direção ao monoteísmo acontece, ou sob o patrocínio, ou em aliança com o poder político, e carrega em si um alto grau de violência [...], tendo uma função importante na legitimação da dominaçấo de um grupo sobre outros"3.

A instituição do monoteísmo se dá por uma sequência de reformas políticoreligiosas, que por trás de um discurso de favorecimento para o povo de Deus escondia interesses de dominações de grupos de pessoas e manutenção de poder. Neste contexto, a mensagem de um Deus universal e libertador apresentada pelo autor do livro de Joel se apresenta como alternativa de resistência para a busca da liberdade dos enfraquecidos.

\section{Reformas judaicas em nome de um monoteísmo marcado pela opressão e desumanização}

Smith ${ }^{4}$ assevera que diferente do que as tradiçóes cristã e judaica afirmam, a revelação sobre Deus não começa na Bíblia, mas nos textos extra bíblicos (antigo Oriente Próximo). Assegura que estudos recentes de contraste entre textos do antigo Oriente Próximo, como os textos ugaríticos do período do Bronze Recente e de outras fontes, versus a Bíblia demonstraram que as articulaçóes do monoteísmo de Israel eram na realidade formulaçóes reformadas do politeísmo israelita antigo, que por sua vez, era uma versão do politeísmo ugarítico e cananeu.

\footnotetext{
${ }^{1}$ Croatto, Isaias: la palabra profética y su relectura hermenéutica, Vol. 2, 81; y 95-100.

${ }^{2}$ López, "Redención de la tierra y del pueblo", 34.

${ }^{3}$ Dietrich, Violências em nome de Deus, 16.

${ }^{4}$ Smith, O memorial de Deus: história, memória e a experiência do divino no Antigo Israel, 132-133.
} 
Smith apresenta algumas observaçôes sobre a evolução do politeísmo para o monoteísmo, que se resume em: (1) O monoteísmo não se originou historicamente no Sinai com Moisés e a aliança feita lá. O próprio Moisés perguntaria: "Quem é igual a você entre os deuses, ó Senhor?” (Ex 15,11). (2) O monoteísmo se desenvolveu na religião israelita monárquica ou pelo menos em segmentos de sua população. (3) Expressóes explicitamente monoteístas realmente emergem em um ponto crucial da religiáo israelita, mas isto não significa negar que havia formas correntes de politeísmo judaíta, nem mesmo negar as pluralidades dentro da divindade no monoteísmo bíblico. (4) Sempre houve algo monista no politeísmo (usava diferentes conceitos para expressar "unicidade" no universo). Em contrapartida, depois do surgimento da linguagem monoteísta na Bíblia (séculos VII e VI), "havia geralmente algo bem 'poli' sobre o monoteísmo: ele carregava em uma deidade muitos tipos diferentes de personalidades, associadas a várias deidades no politeísmo".

Estas observaçóes poderão ser constatadas nas diversas reformas políticoreligiosas ao longo da história do povo de Israel, como veremos a seguir.

\section{Reformas locais que deram os primeiros passos rumo ao monoteísmo}

Dietrich supóe que os primeiros passos em direção ao monoteísmo foram dados por Davi, que torna-se rei após uma série de mortes, sendo algumas em condiçóes suspeitas (1Sm 22-2Sm 5; $2 \mathrm{Sm} \mathrm{16,5-8).} \mathrm{Após} \mathrm{se} \mathrm{tornar} \mathrm{rei} \mathrm{introduz} \mathrm{a} \mathrm{arca} \mathrm{para} \mathrm{dentro}$ das muralhas de Jerusalém (2Sm 6,1-23), um ato realizado com toda pompa militar, com participação de "trinta mil homens da elite do exército de Israel" e marcando a entronização de Javé dos Exércitos como o Deus do rei. "E Davi e a monarquia davídica começaram a ser apresentados como representantes de Javé dos Exércitos, o Deus da arca. O culto a Javé dos exércitos passou a ser uma espécie de culto oficial" 5.

O período da monarquia davídica tem sido interpretado de forma equivocada por alguns teólogos como de predominância do monoteísmo, mas alguns textos (Ex 14, 14.24-25.27; 15,2-3; Dt 1,30; Jz 4,14-15, dentre outras referências) demonstram que na realidade Javé é uma divindade com atuação "limitada" na atuação militar em defesa dos camponeses. Javé, no período da monarquia é uma divindade dentre outras. Dietrich afirma:

...ele era adorado ao lado de outras divindades que eram responsáveis por outras áreas da vida, como Baal, responsável pelas chuvas e pela fertilidade dos

${ }^{5}$ Dietrich, Violências em nome de Deus, 16. 
campos, como El e Asherá e outras divindades responsáveis pela fertilidade das mulheres e dos animais. ${ }^{6}$

Portanto, Davi não deu início ao monoteísmo, mas introduziu os primeiros passos para que o monoteísmo viesse a ser uma realidade para o povo de Israel. Os demais passos importantes em direção ao monoteísmo foram dados por uma sequência de reformas político-religiosas.

As primeiras reformas ocorreram no século IX a. C. com Eliseu e Jeú em Israel, e o sacerdote Joiada, em Jerusalém. Jeú, apoiado por Eliseu, organiza uma trama, um golpe militar, e assassina num só dia os reis de Israel e de Judá (2Rs 9) sob o pretexto de que deveria eliminar a dinastia de Amri (845-841 a. C.), aliada dos fenícios e que havia adotado Baal e Asherá como divindades oficiais (1Rs 16,31-33; 18,19; 2Rs 10,25-27). Entretanto, é provável que a reforma de Jeú atingiu somente os santuários que ele tinha controle: santuário oficial de Samaria e talvez também Betel, Guilgal e Dã (Am 4,4; 5,5; 7,10-13).

Em paralelo a essa reforma de Jeú, no Templo de Jerusalém, o sacerdote Joiada, apoiado pelos guardas do templo e com o povo da terra (2Rs 11,14.18.19.20), também promove um golpe para matar a rainha Atalia (única mulher a ocupar o trono de Jerusalém), última descendente da dinastia de Amri. Todavia, da mesma forma que a reforma de Jeú, a abrangência foi nos arredores do templo. Entretanto, essas duas reformas serviram como um prelúdio para as duas próximas reformas que seriam mais amplas: as reformas de Ezequias e Josias?

\section{As duas reformas político-religiosas mais significativas do período pré-exílico: as reformas de Ezequias e Josias}

Ezequias (716-687 a. C.) começou a reinar no período de domínio do Império Assírio sobre a regiāo da Palestina e logo após o exílio/deportação dos samaritanos, ocorrido aproximadamente em 722 a. C. Contudo, Ezequias resiste, buscando manter um reino independente para Judá. Para isso, amplia o fornecimento de água para a cidade com a construção do chamado "túnel de Ezequias" (2Rs 20,20), aumenta a área da cidade para acolher os fugitivos do reino de Israel e os nobres das 46 cidades dos arredores de Jerusalém tomadas pelo rei assírio Senaquerib em 701 a. C. (2Rs 18,13; 2Cr 32,1), como também reforça a espessura das muralhas da cidade. Segundo Liverani, com as grandes intervençôes urbanísticas de Ezequias e o acolhimento dos refugiados

\footnotetext{
${ }^{6}$ Ibid., 19.

${ }^{7}$ Ibid., 20.
} 
de Samaria "a cidade passou de cinco hectares (em grande parte ocupados por templo e palácio) a sessenta, e a populaçáo provável passou de mil a 15 mil pessoas no espaço de uma geração"s.

Neste contexto, Ezequias inicia a reforma, proibindo a utilização de todos santuários fora de Jerusalém, mesmo que fossem de Javé, centralizando assim, toda adoração e oferendas em Jerusalém. Promove uma aliança exclusiva com Javé, que passou a ser o Deus nacional de Judá, visando a vitória sobre os assírios (2Rs 18,3-6; 2Cr 29,1-31,1). Segundo Dietrich, "os cultos oficiais passaram a atribuir a Javé tanto as funçôes dos Elohim e de El, como também as de Baal, de Asherá, de Astarte e de muitas outras divindades (Dt 28,1-68; cv. 7,12-16; 11,13-17: Ex 12,1-13,16)” ?

Smith afirma que influências politeístas do Israel antigo, no que se refere às características de outras deidades que foram incorporadas por Javé, sobreviveram ao longo do tempo na história de Israel por meio do gênero literário apocalíptico ${ }^{10}$

Contudo, a mais antiga tradição mítica dificilmente foi erradicada ou caiu em desuso no antigo Israel. Ela sobreviveu fortemente na apocalíptica bíblica. Podermos dizer que o conjunto das narrativas politeístas de Israel no passado aparece mais tarde na forma monoteísta como um conjunto apocalíptico no futuro. Parece que Iahweh tinha assimilado as tradições associadas a Baal. Ambos são deuses-guerreiros da tempestade [...]. Esta incorporação de características das outras deidades por Yahweh que durou muito tempo na religião israelita mostra [...] convergência dos papéis divinos atribuídos a Yahweh. ${ }^{11}$

Durante o reinado de Ezequias surge uma série de textos bíblicos da chamada "Obra histórica deuteronomista" (Js, Jz, 1 e 2Sm, 1 e 2Rs), do Pentateuco e de vários livros dos profetas. Segundo Dietrich, a "centralização religiosa foi feita com muita imposição e violência (2Rs 18,4.22; Is 36,7; 2Cr 30,13-14; 31,1)" e com os textos sagrados gerados neste período "o rosto deste Javé oficial violento, exclusivista, centralizador, homogeneizador e intolerante ficou gravado em muitas partes das Bíblia" ${ }^{12}$.

Dietrich afirma "o que Ezequias fez no âmbito de Judá, Josias sonhou fazer em todo Israel” ${ }^{13}$. Segundo Liverani, o Império Assírio atingiu o seu apogeu como

\footnotetext{
${ }^{8}$ Liverani, Para além da Bíblia: história antiga de Israel, 195.

${ }^{9}$ Dietrich, Violências em nome de Deus, 22.

${ }^{10}$ Esta informação é relevante para relacionar o processo de transição do politeísmo ao monoteísmo com a mensagem de Joel, reconhecido como um livro com conteúdo do gênero apocalipse, especialmente os capítulos 3 e 4 (versão católica), que serão utilizados na segunda parte deste artigo.

${ }^{11}$ Smith, O memorial de Deus, 141.

${ }^{12}$ Dietrich, Violências em nome de Deus, 23.

${ }^{13} \mathrm{Ibid}$.
} 
longo reinado de Assurbanipal (668-631), mas nos últimos anos deste rei, o império perdeu o controle das províncias mais distantes e também teve início uma guerra de sucessão que durou vinte anos e desgastou a classe dirigente, as finanças e o exército ${ }^{14}$.

Era a decadência progressiva do império opressor dos israelitas. Josias vê uma grande oportunidade para instituir um reino projetado no ideal das doze tribos unidas. Ele começa sua reforma introduzindo Javé como Deus nacional de Israel, pois o sucessor de Ezequias no reino Norte, Manassés, assim que assumiu o poder reintroduziu o culto a outras divindades em Jerusalém e renovou a aliança com a Assíria (2Rs 21,117). Segundo Dietrich, para justificar seus atos, Josias precisava de algo que the desse legitimação, como uma reforma política-religiosa com base na releitura dos textos sagrados existentes:

A ampliação do domínio político sobre as terras e tribos do Norte, a violência contra os santuários, os Deuses e Deusas cultuadas há séculos, a violência contra seus sacerdotes, sacerdotisas (2Rs 23,5-7.14.16.20) e seguidores necessitava de uma justificativa forte e muito bem elaborada. Com essa função grande parte do atual Pentateuco, dos livros da Obra Histórica Deuteronomista, dos livros dos profetas pré-exílicos, de Provérbios e Salmos foram redigidos de modo a dar suporte teológico e legitimação religiosa para a reforma e o projeto de Josias. ${ }^{15}$

Liverani ${ }^{16}$ comenta sobre o registro no texto bíblico da descoberta de um manuscrito "antigo" no Templo de Jerusalém, provavelmente o atual texto de Deuteronômio 4-28 ${ }^{17}$, e do desespero de Josias ao "perceber" que a lei ficara sem ser aplicada por um longo período. Uma situação providencial para os propósitos do rei, pois se torna possível uma "afirmação central ideologicamente expressiva da reforma" como o primeiro mandamento que incentiva a prática da monolatria ${ }^{18}$ : "Eu sou Javé teu deus, não terás outro deus além de mim". Com a imposiçấo da unicidade do deus, do culto e do lugar de culto (valorização do templo de Jerusalém), aliado com a eliminação dos outros lugares de culto e a celebração da Páscoa de forma inovadora por Josias (2Rs 23,21-22), uma festa de peregrinação que fazia convergir grande número de fiéis do país ao santuário central, o projeto de unificação do ideal das 12 tribos parecia algo possível. Dietrich ${ }^{19}$ destaca, ainda, que nos textos bíblicos desta

\footnotetext{
${ }^{14}$ Liverani, Para além da Bíblia, 211.

${ }^{15}$ Dietrich, Violências em nome de Deus, 24.

${ }^{16}$ Liverani, Para além da Biblia, 222-23.

${ }^{17}$ Dietrich, Violências em nome de Deus, 24. Tem como provável Dt 12-16 ampliado.

${ }^{18}$ Prática de adoração a um só Deus sem deixar de reconhecer a existência de outros deuses, como por exemplo: Ex 20,3; 22,19; Dt 10,17; Js22,22; 95,3; 96,4; 135,5; 136,2-3.
}

${ }^{19}$ Dietrich, Violências em nome de Deus, 25. 
época transparece a ambiguidade da teologia oficial, que envolve o principal adversário político de Josias, o faraó do Egito e seus deuses, como adversário derrotado por Javé no relato do êxodo e da libertação do povo de Israel escravizado (Ex 12,12; 14,25-28; 15,1-11;20,1). Teologia que também é usada para justificar toda a violência necessária para a efetivação da reforma.

Todavia, o projeto de Josias não teve o êxito desejado. Em 609, o faraó Neko sobe a costa da Palestina para lutar contra os babilônicos e Josias vai ao encontro dele em Megido, porém Josias é ferido e morto. Liverani ${ }^{20}$ conjectura a influência do texto "encontrado" no templo na decisão de Josias (Dt 20,1). Ele, talvez, confiado nas palavras divinas não teve medo e partiu para a luta contra o exército bem mais numeroso dos egípcios e foi derrotado e morto. Com ele foi a esperança do povo, pois Neko deporta o herdeiro do trono Yoachaz e coloca outro filho de Josias, Yoyaqim (609-598) com rei tributário ao Egito (2Rs 23,31-35). O exílio babilônico é o destino final do povo de Judá.

\section{A reforma étnica de Esdras e Neemias}

Com a destruição da cidade e, principalmente, do templo de Jerusalém, e o entendimento do fracasso do "projeto de Deus" para o povo, surgem novas crenças em um caminho alternativo com o verdadeiro sentido do propósito universal e eterno de Deus.

As reformas de Jeú, Joiada, Ezequias e Josias foram prelúdios para a instituição do monoteísmo, pois a prática predominante era a monolatria. Em meio a um ambiente de desesperança e opressão, Ezequiel se apresenta como precursor de uma visão renovada e universalista de Deus, ao perceber que Javé não estava somente em Jerusalém, mas também em terra estrangeira, ou seja, com os exilados na Babilônia (Ez 40-48). Renova-se a esperança em uma Jerusalém e um templo renovado ${ }^{21}$. Entretanto, segundo Dietrich, a prática do monoteísmo ${ }^{22}$ somente "foi alcançada entre os exilados da segunda deportação (587 a.C.), na Babilônia, por volta dos anos 550 a. C. .3" com o Dêutero-Isaias (Is 40-55), onde se encontram as afirmaçóes monoteístas mais antigas da Bíblia (Is 42,10-11; 43,10-13; 44,6-8; 45,5-6.21; 46,9).

As demais citações monoteístas são posteriores e quando encontradas em livros anteriores ao Dêutero-Isaias tratam-se de releituras exílicas ou pós-exílicas. O DêuteroIsaias apresenta o coração sagrado e libertador do monoteísmo: a divindade presente

\footnotetext{
${ }^{20}$ Liverani, Para além da Bíblia, 228.

${ }^{21}$ Croatto, Historia de salvación: la experiencia religiosa del pueblo de Dios, 198

${ }^{22}$ Crença de que existe somente um Deus, não admitindo a existência de qualquer outra divindade.

${ }^{23}$ Dietrich, Violências em nome de Deus, 26.
} 
junto aos oprimidos e enfraquecidos, descrita com imagens femininas, geralmente na forma de cuidados maternos (Is 42,14; 49,15; 44,2.24; 46,3; 49,1.5), apresentada como única e verdadeira.

Entretanto, somente na reforma de Esdras e Neemias, durante a dominação do Império Persa é que os escritos bíblicos consolidam o monoteísmo. LienemannPerrin afirma que "nos primeiros dois séculos após o exílio formou-se o judaísmo a partir de Israel, passando de Estado para a comunidade, e de religião cultual e religiáo de escritura" ${ }^{24}$. Donner especifica o momento do surgimento do judaísmo com suas instituiçôes próprias, como sendo na "época da restauração sob Neemias e Esdras"25.

Segundo Fohrer, Neemias atuou durante o reinado de Artaxerxes I (445 a 432 a. C.). Neemias, copeiro do rei persa e oriundo de uma família israelita da Babilônia, é nomeado pelo rei persa como governador de Jerusalém, como uma nova província persa ${ }^{26}$. Ele contribui com a manutenção externa (muro) e interna (remissão geral das dívidas, resgate do recebimento dos dízimos aos levitas, a observância do shabbath e oposiçẫo aos casamentos mistos), mas é Esdras que contribui para a reforma religiosa, ao receber ampla autoridade do rei persa para organizar os negócios da comunidade em Jerusalém "com base num código de leis que Esdras tinha à mão".

Segundo Fohrer, a obra de Esdras, provavelmente a Torá, "lançou base para o período seguinte, de modo que, mais tarde, ele chegou a ser comparado a Moisés e glorificado como o finalizador da obra de Moisés" ${ }^{27}$. Sua obra contribuiu para que o judaísmo primitivo fosse determinado pela lei, com posição central ao ritual cultual, tanto na Judéia como na diáspora babilônica.

Todavia, Dietrich afirma que parte das motivaçôes para a consolidação do monoteísmo nos escritos bíblicos foi o conflito estabelecido com a volta dos exilados que encontraram os latifúndios de seus antepassados ocupados há mais de 50 anos pelos camponeses remanescentes. Eles precisavam de uma legitimação para retomar a posse dos latifúndios, "condenar e excluir os camponeses remanescentes na terra de Judá" ${ }^{28}$. Entre 450 a 400 a. C., os sacerdotes do segundo templo são confirmados como intermediários entre o Império Persa e o povo, sobretudo passaram a exercer o poder em nome de Deus, agora considerado único e universal (Dt 4,39; 1Rs 8,60).

\footnotetext{
${ }^{24}$ Lienemann-Perrin, Missão e diálogo inter-religioso, 24.

${ }^{25}$ Donner, História de Israel e dos povos vizinhos: da época da divisão do reino até Alexandre Magno, 488.

${ }^{26}$ Fohrer, História da religião de Israel, 445.

${ }^{27}$ Ibid., 448.

${ }^{28}$ Dietrich, Violências em nome de Deus, 27-28.
} 
Os elementos libertadores sagrados do monoteísmo são substituídos:

Porém, os elementos libertadores que constituíam a sacralidade do monoteísmo, nascidos na resistência à escravidão do exílio, foram substituídos por uma sacralidade ligada ao nome da divindade, a um lugar sagrado, a um conjunto de determinados rituais e a uma hierarquia sacerdotal bem definida. ${ }^{29}$

A imagem do Javé do segundo templo, no judaísmo primitivo, pode ser vista como um aprofundamento do esforço monolátrico de Josias que transformou o templo salomônico em um símbolo de unidade nacional. Mas, o critério para definir quem pertencia ao povo de Deus passou a ser a pureza racial e o ritual. Javé passa a ser apresentado como o juiz supremo, inacessível, inominável e incansável aplicador da Lei judaica. Um Deus tão santo, transcendente que o uso de seu nome será proibido a todos, com exceção do sumo sacerdote, que poderia proferi-lo uma vez ao ano ${ }^{30}$. A mensagem de Joel surge neste ambiente. Ezequiel e o Deutero-Isaias (Is 40-55) foram os primeiros a introduzirem a mensagem universalista, mas Joel dá continuidade a esta mensagem que trouxe nova esperança para o povo após a restauração de Esdras e Neemias (450 a. C.).

\section{O monoteísmo universal e libertador anunciado por Joel}

Em meio a opressão e marginalidade durante o exílio e pós-exílio, surgiram no meio do povo oprimido novas utopias que desenvolveram esperanças e influenciaram nas relaçóes sociais e na maneira de ver a divindade, que progressivamente passará a uma visão universalista de Deus.

Segundo Godoy, "o livro de Joel não é muito conhecido no âmbito bíblicoteológico latino-americano" ${ }^{31}$, demonstrando que pouco se tem escrito a respeito deste livro. Ele chega a essa conclusão por meio da pesquisa de sua tese de doutorado, em que faz um levantamento bibliográfico sobre as produçóes sobre o livro de Joel ou seu protagonista. Esta escassez de produção científica sobre o livro e Joel não desmerece a importância do livro, mas desperta ainda mais o interesse em estudá-lo e descobrir "revelaçôes" que possibilitem releituras novas e subsídios para um despertar de esperança para os leitores deste livro.

O nome de Joel é uma composição de uma forma abreviada do nome de Deus acrescido da palavra hebraica el, que juntos significam "Javé é El/Deus". Rossi afirma

${ }^{29}$ Ibid.

${ }^{30}$ Gallazzi, "Por medio de él: el designio de Dios ha de triunfar", 23.

${ }^{31}$ Godoy, O derramamento do espírito: fortalecimento dos enfraquecidos, 31. 
que o significado do nome de Joel é uma forma de "proclamação de fé no Deus de Israel", e enfatiza que o profeta "traz consigo uma certeza que fará diferença na crise em que ele e o povo estão envolvidos" ${ }^{2}$.

Uma das maiores polêmicas ou problemas do livro é situá-lo historicamente. Sicre inicia o comentário sobre o profeta Joel com a seguinte afirmação: "Na etapa final da profecia israelita podemos incluir um livro de dataçâo muito difícil, o de Joel" ${ }^{33}$. Hubbard afirma que dentre os especialistas, as proposiçóes de datação vão do século IX a. C. até o século II a. C. ${ }^{34}$. Enquanto que Rendtorff, ao comentar sobre o cânone hebraico, afirma que os livros proféticos abrangem um tempo longo que vai do século VIII até o século IV a. C. e nesse bloco literário destaca os seguintes livros como pertencentes ao período pós-exílico: Joel, Jonas, Terceiro Isaías, Ageu, Zacarias e Malaquias ${ }^{35}$.

Triana Fernández comenta que o problema da unidade do livro de Joel também é um dos temas mais discutidos entre os estudiosos. Ele defende a unidade do livro de Joel, entretanto deixa em aberto o questionamento se os quatro capítulos do livro são da mão do mesmo autor ou não, mesmo argumentando que as diferenças de estilo comprovem a diversidade de autoria ${ }^{36}$. Reforça a dependência de profetas anteriores e a singularidade de mensagem de Joel ${ }^{37}$ : um profeta escatológico, ou seja, que escreve profecia e ao mesmo tempo utiliza o gênero literário apocalíptico. Recentemente, a editora Paulinas publicou o livro de Fernandes, que exaustivamente demonstra a unidade da mensagem da redação final do livro de Joel, com base no tema "dia de Yahweh", presente nos quatros capítulos do livro ${ }^{38}$.

Portanto, devido à limitação de espaço, este artigo não irá aprofundar na questão da data e unidade, mas tomará como base o período mais aceito entre os estudiosos atuais (século IV ao século II a. C.), sem se preocupar em definir uma data exata para a edição final do livro, também será considerado a unidade da mensagem do livro, por

\footnotetext{
${ }^{32}$ Rossi, Como ler o livro de Joel, 9.

${ }^{33}$ Sicre, Profetismo em Israel: o profeta, os profetas, a mensagem, 325.

${ }^{34}$ Hubbard, Joel e Amós: introdução e comentário, 27-31. Os teólogos mais conservadores (Kapelrud, Joel Studies, 191; Koch, The Prophets, 158-159) defendem a datação mais antigas, enquanto os mais críticos e acadêmicos defendem uma a data mais recente (Rossi, Como ler o libro de Joel).

${ }^{35}$ Rendtorff, A formação do Antigo Testamento, 26-27.

${ }^{36}$ Triana Fernández, “Caminar hacia la esperanza: una lectura de Joel 3.1-5”, 10-11.

${ }^{37}$ Ibid., 26.

${ }^{38}$ Para mais detalhes ver: Fernandes, $O$ anuncio do Dia do Senhor: significado profético e sentido teológico de Joel 2,1-11.
} 
meio de um redator final que finalizou o trabalho dentro do período acima citado, com características do gênero apocalipse, em especial, nos dois últimos capítulos $\left(3\right.$ e 4) ${ }^{39}$. A hora de Joel é de profunda crise. Seu livro tem somente quatro capítulos e crises intermináveis. Nem sempre nos lembramos desse livro da Sagrada Escritura. Às vezes só é lembrado por causa dos versos citados em Atos 2,17-21. No entanto, o livro de Joel se reveste de muita importância. Quem o conhece está mais preparado para viver e passar pela hora de crise.

Joel é um dos chamados profetas menores. Esse título não é dado porque eles sejam menos importantes do que os profetas maiores, mas sim porque escreveram textos mais resumidos, isto é, menores. $\mathrm{Na}$ série dos Doze Profetas o livro de Joel ocupa o segundo lugar, logo após o livro do profeta Oséias e antes do livro do profeta Amós. O livro não fornece informaçôes adicionais sobre o autor, não comenta sobre personagens bíblicos conhecidos e nem cita fatos históricos que permitam uma datação adequada da redação do livro.

A posição do livro de Joel entre os doze profetas menores foi por longo tempo utilizada como argumento pelos defensores de uma redaçáo mais antiga do livro de Joel, situando-o como contemporâneo de Oséias ou Amós (século VIII a. C.). Aliado a isso, o fato de não ser mencionado a figura do sumo sacerdote, que ocupava uma posiçáo central no pós-exílio, bem como a qualidade poética do autor que se equipara com os autores clássicos do período pré-exílico, também têm sido argumentos para defender uma data remota da redaçáo do livro.

No entanto, a datação antiga do livro de Joel já é algo superado. Existem muitas informaçôes curiosas no livro de Joel que justificam a datação mais recente. Num primeiro momento podemos destacar que em Joel nunca se menciona o rei; por outro lado, o texto faz referências aos sacerdotes $(1,9.13-14)$ e aos anciãos $(1,2)$. Outro fato pitoresco é que em Joel não ouvimos falar dos tradicionais inimigos de Israel, isto é, os assírios e os babilônios. Em cena estão somente aqueles povos que mantiveram relação com Israel no chamado pós-exílio, em especial a referência aos gregos $(4,6)$. Ainda devemos chamar a atenção para outro fato importante: quando no texto de Joel se fala em Israel, ele é identificado com Judá e não mais com as tribos do Norte. O interesse do profeta não está voltado para o Norte (4,1-2), mas exclusivamente para os habitantes de Judá e de Jerusalém (4,1.6.19).

É interessante observar que Joel parece demonstrar relativo conhecimento da vida religiosa praticada em Jerusalém. Possivelmente tenha exercido sua vocação

\footnotetext{
${ }^{39}$ Considerando a numeração de capítulos das versôes católicas (quatro capítulos), que diferem das versões protestantes e evangélicas (três capítulos), ambas contendo o mesmo conteúdo.
} 
profética na cidade de Jerusalém e, se assim o for, é aos habitantes dessa cidade que ele se dirige (2.23). Não podemos ampliar o público focado pelas palavras de Joel. Ele, certamente, não fala para todas as pessoas. É a cidade de Jerusalém que se encontra em perigo $(2,9)$.

Percebe-se logo que a mensagem do profeta é muito bem direcionada à uma cidade e sua população que vive desconectada entre a prática da religião e a vida. Não é a primeira vez que Jerusalém se encontra na ordem do dia relativamente à palavra profética. Muitos anos antes de Joel, o profeta Isaías 1,21-23 fez um retrato paradigmático às avessas de como a cidade de Jerusalém se afastou do projeto de Javé:

Como se transformou em prostituta a cidade fiel. Antes era cheia de direito, e nela morava a justiça; agora está cheia de criminosos! Sua prata se tornou escória, seu vinho ficou aguado. Seus chefes são bandidos, cúmplices de ladróes: todos eles gostam de suborno, correm atrás de presentes. Não fazem justiça ao órfão, e a causa da viúva nem chega até eles.

Não devemos nos esquecer que Joel é um profeta pró-templo. Com isso quero deixar claro que a resposta para a celebração errada que se fazia não era a extinção do Templo e do culto, mas uma celebração correta. Os textos de Joel nos levam a essa conclusão ao nos mostrar Javé habitando em Jerusalém, no monte Sião, o local do Templo de Salomão e de Zorobabel. No entanto, para continuar existindo será necessário conversão e arrependimento!

Todavia, um dos argumentos mais convincentes para a autoria mais recente é a característica literária de Joel, em especial, os últimos capítulos que contém descriçôes escatológicas e apocalípticas.

Pode-se verificar com certa facilidade a abundância em Joel de passagens paralelas aos livros proféticos e a outros livros do Antigo Testamento. Todavia, a facilidade acaba nessa constataçáo e outra dificuldade entra em cena. Náo há acordo entre os estudiosos quanto a determinar em que sentido aconteceu esse relacionamento, ou seja, se é Joel que depende dos demais ou se são os outros profetas que citam Joel. A tendência, atualmente, é para a dependência literária do profeta em relação aos que $\mathrm{o}$ antecederam. E visto que, entre os profetas citados, aparece também Malaquias $(2,11 ; 3,4 ; 3,2.23)$, pode-se pensar que Joel tenha escrito o seu livro depois dele.

Portanto, estamos no pós-exílio no início do século IV a. C., e isso já nos leva a perceber contornos especiais e específicos para Judá nessa época. Devemos estar atentos a essas características. Mas quais são elas?

1. Judá não é mais um reino independente.

2. Depois da queda do reino de Israel, a Samaria foi transformada em província Assíria. Os reis neobabilônicos não mudaram essa posição. Judá, por sua vez, não recebeu um status especial, tal como uma província. 
3. Jerusalém fazia parte da província da Samaria e era dependente administrativamente da satrapia da Transeufratênia.

4. O povo de Deus se descobre como uma pequena etnia perdida nas imensidóes de um império multirracial.

5. É obrigado a se submeter a um rei estrangeiro que ditará normas e leis.

6. Paga tributo e convive com um exército de ocupação.

7. Não controla nem decide mais o seu destino.

8. Não tem esperança de uma independência política num futuro imediato.

9. A relação entre as aldeias, que eram as unidades produtivas de Israel, e o Império Persa se realizava de duplo modo: (a) o governador persa, sediado em Samaria, extraía tributos das aldeias; (b) e mantinha o consenso social mediante o sacerdócio de Jerusalém provindo do exílio babilônico e comprometido, pela sua posição, com o próprio Império Persa.

A perícope de Joel 3,1-5 demonstra a universalidade da mensagem do livro de Joel bem como a inclusão de todos povos na bênção de Deus:

${ }^{1}$ Depois disso, derramarei o meu espírito sobre todos os viventes, e os filhos e filhas de vocês se tornarão profetas; entre vocês, os velhos terão sonhos e os jovens terão visões! ${ }^{2}$ Nesses dias, até sobre os escravos e escravas derramarei o meu espírito! ${ }^{3}$ Farei prodígios no céu e na terra: sangue, fogo e colunas de fumaça. ${ }^{4} \mathrm{O}$ sol vai se mudar em trevas, e a lua em sangue, diante da chegada do Dia de Javé, grandioso e terrível! 'Então, todo aquele que invocar o nome de Javé será salvo, pois a salvação estará no monte Sião e em Jerusalém -como disse Javé- e entre os sobreviventes estarão aqueles que Javé tiver chamado. ${ }^{40}$

Em meio ao contexto do período posterior do segundo templo, o autor do livro de Joel, proclama que o Espírito de Deus seria derramado sobre toda a humanidade, sem exceçâo de idade, gênero e situação social. Uma esperança revolucionária em uma sociedade patriarcal e escravocrata. Joel explicita claramente a opção de Deus pelos menos favorecidos e enfraquecidos.

A mensagem de Joel, embora influenciada pelo pensamento profético cultual e oficial, que proclama a salvação e libertação oriunda de Sião e Jerusalém, foi uma mensagem revolucionária de libertaçáo e esperança para seu tempo. Algo novo e revolucionário, pois apresenta um Deus que se interessa e inclui as pessoas oprimidas, enfraquecidas e marginalizadas em todas as naçóes, fazendo delas profetas e profetisas, portadores da palavra de Deus. Com certeza, uma crítica expressiva às estruturas

${ }^{40}$ Bíblia Sagrada Online. 
políticas, sociais e econômicas resultantes da reforma étnica e patriarcal de Esdras e Neemias, bem como a estrutura religiosa, liderada pela elite sacerdotal e masculina, favorável ao imperialismo persa, bem como ao imperialismo grego-macedônico, que legitimavam em nome da religião suas práticas opressoras.

Trata-se de uma mensagem universalista que ultrapassa geraçóes aberta a novas releituras como aconteceu na igreja primitiva, em que o apóstolo Pedro faz menção de Joel 3,1-5 para justificar o ocorrido no evento de Pentecostes, contextualizando e atualizando a mensagem para seus dias. Visão universalista da salvaçáo tanto para judeus como para gentios defendida exaustivamente pelo apóstolo Paulo em textos como de Gl 3,6-14, Rm 4,1-25; 10,4, dentre outros.

Outra perícope de Joel que contribui para a opinião desenvolvida nessa pesquisa é o capítulo quatro, em especial Jl 4,4-8, que fala sobre o tratamento com os escravos.

${ }^{4}$ E vocês, o que querem de mim, Tiro, Sidônia e distritos da Filistéia? Vocês, por acaso, vão se vingar de mim? Se pensarem nisso, faço recair essa vingança sobre suas próprias cabeças. ${ }^{5}$ De fato, vocês roubaram minha prata e meu ouro, levaram para seus templos os meus tesouros. ${ }^{6}$ Vocês venderam aos gregos os filhos de Judá e de Jerusalém, somente para afastá-los de sua terra. ${ }^{7}$ Pois agora, eu vou tirá-los do lugar para onde foram vendidos. Faço voltar contra vocês aquilo que vocês praticaram: ${ }^{8}$ pela mão dos filhos de Judá, venderei os filhos e filhas de vocês, e eles os venderão à distante nação dos sabeus. Assim falou Javé. ${ }^{41}$

O povo de Israel após o exílio babilônico passa por constantes opressóes sob o jugo dos impérios mundiais como o persa, o grego e o romano. O Império Persa que por trás da imagem de um povo tolerante com seus dominados, aperfeiçoou modo de produção tributário, que com o auxílio da elite judaica, explorava duplamente os judeus, principalmente os camponeses, não foi o pior opressor de Israel. A dominação dos gregos (333-63 a. C.), povo citado por Joel como comerciantes de escravos, soube aproveitar a organizaçáo já instaurada pelos persas e ampliou, implementando o modo de produção escravista

No mundo bíblico podem ser identificados três modos de produção: (1) o tribal; (2) o tributário; (3) o escravista. O quadro abaixo resume os três modos de produção:

${ }^{41}$ Ibid. 


\begin{tabular}{|c|c|c|}
\hline $\begin{array}{c}\text { MODO DE PRODUÇÃOO } \\
\text { TRIBAL }\end{array}$ & $\begin{array}{c}\text { MODO DE PRODUÇÃO } \\
\text { TRIBUTARISTA }\end{array}$ & $\begin{array}{c}\text { MODO DE PRODUÇÃO } \\
\text { ESCRAVISTA }\end{array}$ \\
\hline $\begin{array}{l}\text { Economia de partilha. } \\
\text { Troca de serviços. } \\
\text { Não há comercialização de } \\
\text { produtos. } \\
\text { Valorização do coletivo. } \\
\text { Terra como um bem comum } \\
\text { Apropriação do produto em } \\
\text { base igualitária. } \\
\text { Intercâmbios comerciais } \\
\text { quase inexistentes. } \\
\text { Sem estrutura de classe. } \\
\text { Excedentes de produção são } \\
\text { revertidos em favor do povo. } \\
\text { Terra, pastagens e rebanhos } \\
\text { sáo propriedades do clá ou } \\
\text { da tribo. } \\
\text { Condição para uso dos meios } \\
\text { de produção: pertença à } \\
\text { comunidade. }\end{array}$ & $\begin{array}{l}\text { Baseado em impostos e tributos. } \\
\text { Economia dominada pelos reis, } \\
\text { dignitários da corte, chefes do } \\
\text { exército, sacerdotes chefes do } \\
\text { Templo, grandes comerciantes e } \\
\text { proprietários de terra. } \\
\text { Exercício da política e da economia } \\
\text { a partir da cidade, com apoio do } \\
\text { exército e do Templo. } \\
\text { Maneiras de pagamento de } \\
\text { impostos: produtos, moeda ou dias } \\
\text { de trabalhos forçados. } \\
\text { Excedente da produçáo pertence a } \\
\text { minoria dominante. } \\
\text { Divisão de grupos sociais } \\
\text { (exploradores e explorados) }\end{array}$ & $\begin{array}{l}\text { Economia que reduz tudo a } \\
\text { mercadoria. } \\
\text { Surgimento da classe } \\
\text { de homens livres que } \\
\text { não trabalham e têm a } \\
\text { subsistência garantida. } \\
\text { Mão de obra permanente de } \\
\text { escravos. } \\
\text { Terra como propriedade } \\
\text { privada. } \\
\text { Excedente de produçáo } \\
\text { pertence aos proprietários } \\
\text { de terra. } \\
\text { Economia mercantil } \\
\text { suficientemente } \\
\text { desenvolvida, inclusive de } \\
\text { escravos. } \\
\text { Intercâmbios comerciais com } \\
\text { outras regiōes (excedente). } \\
\text { O valor do escravo tem } \\
\text { como base o corpo e a } \\
\text { capacidade de produção. }\end{array}$ \\
\hline
\end{tabular}

O texto de Joel 4.4-8, em especial o versículo 6: "Vocês venderam aos gregos os filhos de Judá e de Jerusalém, somente para afastá-los de sua terra”, demonstra a insatisfação do Deus, agora universal, com a prática do modo de produção escravista grego. $\mathrm{O}$ autor coloca na boca de Deus o anúncio de julgamento do imperialismo e da libertação dos escravos judeus, bem como os demais, que estavam sendo submetidos a práticas de desumanização. Todavia, os versos sete e oito demonstram ambiguidade da mensagem inclusiva e libertadora de Joel. A prática reprovada dos escravizadores, agora se torna a mesma que é recomendada pelo autor, ou seja. A prática é a mesma, somente muda o lugar dos atores: escravizados passam a serem escravizadores. "Olho por olho, dente por dente". O modo de produção escravista ocorre quando a economia tem como base a comercialização da máo de obra escrava como a principal fonte de produção, inclusive com a separação da pessoa escravizada de sua própria 
sociedade, sendo levada para um novo ambiente no processo de dessocialização e despersonalização. Nesse modo de produção as pessoas são consideradas como coisas. Ribeiro afirma que o modelo de produção escravista interfere na forma de convívio social da sociedade:

O núcleo do social identificava-se com a escravidão. Propriedade adquirida por fatores de hereditariedade, captura, aprisionamento em guerras, mercantilização, venda dos genitores, abandono de recém-nascidos, rapto, pirataria ou quitação de dívidas. Por meio dela o homem era convertido num bem ou numa propriedade privada móvel. ${ }^{42}$

Nesse modelo ocorria o pleno desenvolvimento da propriedade privada e a exploração de uma classe por outra. De um lado estavam os donos de escravos e dos meios de produção (terras e instrumentos de produção) e, de outro lado, estavam os escravos, mão de obra de produção de bens, tratados simplesmente como objetos, máquinas humanas. $\mathrm{O}$ escravo era considerado como qualquer outro instrumento de produção (animal ou ferramenta). Dessa forma, no modelo de produção escravista, as relaçôes de produção eram de domínio e de sujeição, onde os proprietários das terras e instrumentos de produção dominam e os escravos se sujeitam aos seus donos. Os escravos náo tinham direito a nada e o produto do trabalho era todo dos proprietários.

A nova economia grega tinha como eixo central o comércio, que passou a exigir mercadoria excedente para exportação. Para a produção de mercadorias excedentes era necessário cada vez mais trabalho, que por sua vez, não era executado pelo cidadão livre. Então, quem iria produzir essas mercadorias? Evidentemente que seriam os escravos, pois segundo Konzen e Walker "o homem livre não trabalha, ou então trabalha o mínimo possível. Cabem-lhe coisas mais 'nobres', como ao cultivo do saber (filosofia), da beleza (arte), do lazer (esporte) etc.” ${ }^{43}$.

Os escravos recebiam tratamento diferenciado nas regióes econômicas da Grécia onde o modo de produçáo era escravista, caracterizadas, conforme já mencionado, pela propriedade privada da terra e pela supremacia do controle das cidades estado. Segundo Ribeiro "o cerne do poder está na cidade. A partir dela se organiza o todo econômico envolvente e os territórios circundantes". Acrescenta que a sociedade escravista "era expansionista, dinâmica e mutante - diferindo, portanto, da sociedade oriental "fechada"' (modo de produção tributário) ${ }^{44}$. Com a ascensão de Alexandre, o Grande (356-323 a. C.), e o estabelecimento de uma monarquia universal, a difusão da cultura helênica foi sem precedente. $\mathrm{O}$ movimento de fusão e interação cultural entre

\footnotetext{
${ }^{42}$ Ribeiro, "A geografia do modo de produção escravista", 80.

${ }^{43}$ Konzen e Walker, "Noventa cabeças por um talento: sobre a escravidão no tempo dos Macabeus", 49.

${ }^{44}$ Ribeiro, "A geografia do modo de produçâo escravista", 79.
} 
o império grego e demais naçóes, em que o modo de vida grega vai sendo imposto sobre os demais povos, é designado de helenismo ${ }^{45}$.

Uma parte da população da região da Palestina aderiu ao helenismo, em especial, a elite judaica. Entretanto, parcelas da populaçáo, que rejeitavam radicalmente a dominação estrangeira, se mantinham fiéis à cultura e a Javét ${ }^{46}$. Dentre estes é que surge a revolução camponesa que emerge com objetivo de conter as açóes desumanizadoras do imperialismo estrangeiro. Muitas pessoas não se davam conta do que estava por trás da nova economia grega, pois estavam deslumbradas com o "avanço" do comércio. Konzen e Walker asseveram que a escravidão "era inevitável. Vinha junto com o 'pacote' da nova economia”. Os pobres camponeses judeus percebiam na própria pele, ou melhor, na própria família, no dia a dia de suas vidas. Vítimas de constantes visitas dos inimigos, em especial no período dos selêucidas. "Os pobres o sentiam na carne, embora muitos só viam brilho na nova economia" ${ }^{4}$.

Com a morte dos judeus que resistiam ao sistema helênico, a venda das mulheres e crianças judias para estrangeiros, a nação e o judaísmo corriam sério risco de extinção. Os camponeses lutavam para manter sua cultura, sua religião, suas terras, sua liberdade e, sobretudo, lutavam pela sua identidade e dignidade. A mensagem de um Deus universalista e libertador pode ter motivado os membros da insurreição macabaica a dar continuidade às açôes de libertação, crendo na intervenção divina. Entretanto, sabe-se que a conquista macabaica não foi definitiva e nem isenta de abusos de poder e opressão por parte de seus líderes.

\section{Consideraçoes finais}

Neste artigo ficou evidenciado que as reformas politico-religiosas, em especial as duas mais importantes e abrangentes reformas pré-exílicas realizadas por Ezequias e Josias, bem como a reforma pós-exílica liderada por Esdras e Neemias, formalizaram a centralização da religiáo no templo de Jerusalém e no culto a Javé como Deus único com objetivos econômicos, políticos e militares. Alguns escritos sagrados que surgiram na época serviram, por vezes, para legitimar açóes muitas vezes violentas. A teologia oficial deste período, por conta disso, se apresenta ambígua, pois ao mesmo tempo que conduz à adoração ao Deus Javé, legitima uma série de de violência e de dominação sobre os enfraquecidos.

No que se refere a proposta do universalismo e libertação de Joel, embora não se isenta de ambiguidades, ela foi inovadora e provocadora de resistência e busca de

\footnotetext{
${ }^{45}$ Koester, Introduction to the New Testament. History, Culture and Religion of the Hellenistic Age, Vol. 1, 39.

${ }^{46}$ Kessler, História social do antigo Israel, 50.

${ }^{47}$ Konzen e Walker, “Noventa cabeças por um talento: sobre a escravidão no tempo dos Macabeus”, 49.
} 
transformação de uma realidade de exclusão e desumanização. Cabe aos leitores atuais avaliarem a relevância da mensagem deste autor para as pessoas que vivem no mesmo contexto de opressão e desumanização, quer fora do país ou mesmo em comunidades e até em um ambiente familiar. Pessoas que em meio a renovação de sonhos e esperanças possam superar sua situação de crise e mudar sua realidade de vida. Quem dera um sonho e esperança de uma solidariedade universal para mudar a realidade do mundo e de muitas pessoas que já não têm mais esperança e "enterraram" seus sonhos.

\section{Bibliografia}

Bíblia Sagrada Online. Edição Pastoral. Disponível em: Paulus Editora, http://www. paulus.com.br/biblia-pastoral/_PTG.HTM (acesso em 25 novembro 2014).

Croatto, José Severino. Historia de salvación: la experiencia religiosa del pueblo de Dios. Estella (Navarra): Verbo Divino, 1995. . Isaias: la palabra profética y su relectura hermenéutica. Vol. 2. Buenos Aires: Lumen, 1994.

Dietrich, Luiz José. Violências em nome de Deus. São Leopoldo (RS): CEBI, 2013.

Donner, Herbert. História de Israel e dos povos vizinhos: da época da divisão do reino até Alexandre Magno. São Leopoldo: Sinodal, 2006.

Fernandes, Leonardo Agostini. $O$ anuncio do Dia do Senhor: significado profético e sentido teológico de Joel 2,1-11. São Paulo: Paulinas, 2014.

Fohrer, Georg. História da religião de Israel. São Paulo: Paulinas, 1983.

Gallazzi, Sandro. "Por medio de él: el designio de Dios ha de triunfar". Revista de interpretación biblica latinoamericana 21 (1995): 11-34.

Godoy, Daniel. “O derramamento do espírito: fortalecimento dos enfraquecidos”. Tese (Doutorado em Ciências da Religião), Universidade Metodista de São Paulo, Faculdade de Filosofia e Ciências da Religião, São Paulo, 2001.

Hubbard, David Allan. Joel e Amós: introdução e comentário. São Paulo: Vida Nova, 1996.

Kapelrud, Arvid S. Joel Studies. Uppsala e Leipzig: A. B. Lundequistska Bokhandeln e Otto Harrassowitz, 1948.

Kessler, Rainer. História social do antigo Israel. São Paulo: Paulinas, 2009.

Koch, Klaus. The Prophets. Vol. 1. The Assyrian Period. Philadelfia: Fortress Press, 1983. 
Koester, Helmut. Introduction to the New Testament: History, Culture and Religion of the Hellenistic Age. Vol. 1. New York: Bu Walter de Gruyter \& Co., 1980.

Konzen, Léo Zeno e Décio José Walker. "Noventa cabeças por um talento: sobre a escravidão no tempo dos Macabeus". Estudos bíblicos 18 (1998): 45-52.

Lienemann-Perrin, Christine. Missão e diálogo inter-religioso. São Leopoldo (RS): Sinodal, 2005.

Liverani, Mário. Para além da Bíblia: história antiga de Israel. São Paulo: Paulus e Loyola, 2008.

López, Rolando. "Redención de la tierra y del pueblo". Revista de interpretación bíblica latinoamericana 18 (1994): 31-42.

Rendtorff, Rolf. A formação do Antigo Testamento (5. a ed.). São Leopoldo: Sinodal, 1998.

Ribeiro, Júlio Cézar. "A geografia do modo de produção escravista”. Revista Eletrônica da Associação dos Geógrafos Brasileiros (1989).

Rossi, Luiz A. S. Como ler o livro de Joel. São Paulo: Paulus, 1998.

Sicre, José Luis. Profetismo em Israel: o profeta, os profetas, a mensagem (3. ${ }^{\text {a }}$ ed.). Petrópolis: Vozes, 2008.

Smith, Mark S. O memorial de Deus: história, memória e a experiência do divino no Antigo Israel. São Paulo: Paulus, 2006.

Triana Fernández, Pedro J. "Caminar hacia la esperanza: una lectura de Joel 3.1-5". Dissertação (Mestrado em Ciências da Religião), Universidade Metodista de São Paulo, São Bernardo do Campo, 1994. 